\title{
DIE PREPON-BEGINSEL IN DIE METAMORPHOSES VAN OVIDIUS
}

\author{
D J Coetzee (Universiteit van die Oranje Vrystaat)
}

Ovidi Medea videtur mihi ostendere quantum ille vir praestare potuerit, si ingenio suo imperare quam indulgere induisset ...

Die Medea van Ovidius toon myns insiens watter hoogtes daardie man kon bereik het as hy sy vindingrykheid kon beheer het eerder as om hom daarin te verlekker ...

Quintilianus Inst. 10.1.98

\section{Samevatting}

Die prepon-beginsel met sy gerigtheid vanuit verskeie hoeke op wat gepas is, veral op letterkundige gebied, het sterk geleef in die gees van die klassieke mens. In die tyd van Ovidius was daar reeds 'n soort tradisie in verband met wat as gepas beskou is in die onderskeie letterkundige genres. In hierdie artikel val die fokus op die Metamorphoses van Ovidius en word die vraag gestel of die outeur in hierdie verhalende gedig hom gehou het by die tradisionele prepon-beginsels.

\section{$1 \quad$ Die prepon-beginsel}

Die bywoord $\pi \rho \varepsilon \pi \delta ́ \nu \tau \omega \varsigma$, afgelei van die onpersoonlike werkwoord $\pi \rho \varepsilon \pi \varepsilon \iota$, se primêre betekenis word in Liddell and Scott aangedui as: "Dit wat uitstaan en sterk spreek tot die sintuie." 'n Verdere betekenis wat aangedui word, is: "Dit wat besonder eenders is of in ooreenstemming met iets anders is." Hieruit vloei die betekenis voort van: "Dit wat besonders gepas of behoorlik is" ("to be conspiciously fitting, beseem"). In laasgenoemde betekenis word die prepon-beginsel, volgens Drijepondt (1979:134 e.v.), reeds deur Plato (Gorgias 503E) en Isokrates (Philippos 110) met betrekking tot kuns aangewend. In sy Rhetorica Boek 3 begin Aristoteles, volgens Drijepondt, die gesubstantiveerde deelwoord $\tau \grave{o} \pi \rho \varepsilon \dot{\pi} \pi \nu$ aanwend in verband met gepastheid tussen letterkundige styl en stof, veral in dié gedeeltes waar etos en patos ter sprake kom. As Theophrastus die werk van sy leermeester in 'n vaste sisteem neerpen, neem $\pi \rho \varepsilon \dot{\pi} \pi \nu$, volgens Solmsen (1941:43 e.v.), naas korrekte

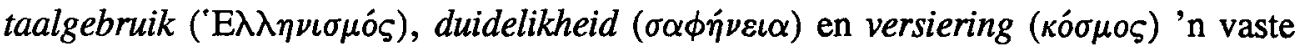
plek in as een van die vereistes vir goeie styl (die sogenaamde $\dot{\alpha} \rho \varepsilon \tau \alpha i \grave{\lambda} \varepsilon^{\prime} \xi \varepsilon \omega \varsigma$ ).

Onder Aleksandrynse invloed verkry die prepon-beginsel in poësie 'n wyere betekenis en word ook aspekte soos gepaste handelinge en ooreenstemming met die werklike lewe daarby ingesluit (Pohlenz 1933:53-92). Wat die prepon-leer onder die Romeine betref, het, volgens Pohlenz (1933:53 e.v.), veral die Stoïsyn, Panaitius 'n sterk invloed uitgeoefen deurdat die prepon-beginsel vanuit sy filosofies-etiese beskouinge deurgewerk het op die retoriek en poësie van sy tyd. Cicero sluit hom 
aan by die Griekse prepon-tradisie as hy in sy $D e$ or. 3.37 by wyse van 'n retoriese vraag onderstreep dat die korrekte wyse van redevoering tog immers korrekte taalgebruik, duidelikheid, versiering en gepastheid ten opsigte van die besondere saak onder bespreking impliseer. ${ }^{1}$

Uit die bogenoemde is dit dus duidelik dat die prepon-leer soos dit ontwikkel het, só wyd toegepas is dat dit feitlik ondefinieerbaar geword het. Pohlenz (1933:55) som dit myns insiens raak op deur te sê dat die prepon-teorie in breedste sin verstaan moet word as 'n soeke in die gees van die klassieke mens wat spruit uit sy voorliefde vir welgevormdheid en proporsionalitiet van sintuiglik waarneembare verskynsels, maar ook vir harmonie tussen verskyningsvorme en die kunstige weergawe daarvan, sowel as tussen die vorm van weergawe en die inhoud daarvan, asook tussen die afsonderlike dele en die geheel ("Die ganze Theorie wurzelt in der Tiefe des griechischen Geistes, in seinem Gefallen an Wohlgeformtheit und Proportionalität tot der sinnlichen Erscheinung Erscheinung, aber auch an der Harmonie von Erscheinung und Wesen, von Darstellungsform und Inhalt, von Einzelgeste und Gesamthaltung").

Brink (1971:463-464) tree myns insiens in lyn met die sienswyse hierbo op as hy sê dat decorum (Cicero se Latynse weergawe vir $\pi \rho \varepsilon \dot{\pi} \pi \nu$ ) vir Horatius in sy Epistula ad Pisones nie meer maar net een van die stylvoortreflikhede (virtutes dicendi) is nie, maar 'n allesoorheersende, allesomvattende eis vir goeie literatuur. Die vele aspekte wat deur hierdie veelduidende term geïmpliseer word, kom duidelik na vore as Brink (1971:463 e.v.) dit met betrekking tot die Ars Poetica onder andere in verband bring met:

- The unity of poetic texture against the multiplicity of subjects and tones;

- The proper arrangement of topics;

- Appropriateness in the choice of words;

- Diction vis-à-vis metre and genre or emotion or character;

- Consistancy in the drawing of persons either historical or fictional;

- The legitimus sonus of rhythm.

\section{Ovidius en die prepon-beginsel}

Ovidius, wat in 43 v.C. gebore is, het nie die verskrikking en lyding van die burgeroorloë aan eie lyf gevoel soos sy meer ernstige voorgangers, onder wie veral Vergilius en Horatius, nie. Galinsky (1975:43) verwoord dit: "Ovid was born too late to have lived through the horrors of the civil wars and thus to have gained a deeply personal appreciation of Augustan peace.... He was indifferent to Augustus' moral and antiquarian program and he treated Augustan themes lightly." Nie alleen was daar ' $n$ generasiegaping tussen Ovidius en sy meer ernstige voorgangers nie, maar in vele opsigte was daar ook 'n wegbreek van wat tradisioneel as gepas, as prepon beskou is. Veral die volgende aspekte kan in dié verband uitgesonder word:

1 Quinam igitur dicendi est modus melior ... quam ut Latine, ut plane, ut ornate, ut ad id quodcumque agitur apte congruenterque dicamus? 


\subsection{Ovidius en die gode van Olympus}

Om 'n vergelyking te kan tref tussen die hantering van die gode van Olympus deur Ovidius en die hantering van die gode deur sy voorgangers, word hier veral gelet op Homerus en Vergilius as prepon-maatstaf.

Erbse (1986:295-305) sê dat die Olimpiese gode heel moontlik hul oorsprong te danke gehad het aan die Ioniese kuns in Klein-Asië. Dit was egter Homerus en later Hesiodus wat in hul literatuur aan die stambome, byname, ampte, gesagsgebiede en voorkoms van die gode 'n bepaalde vorm in literatuur gegee het. Dat die gode van Homerus en Hesiodus blote menslike skeppinge was, blyk duidelik uit die kritiek van Xenophanes, soos aangehaal by Feeney (1991:3), teen die hantering van die gode by Homerus en Hesiodus. Xenophanes (550-478 v.C.), wat seker as die eerste literêre kritikus beskou kan word, se kritiek teen Homerus en Hesiodus is dat hulle die gode vereenselwig met alles wat volgens die mense skandalig is, nl. diefstal, egbreuk, bedrog, ens. Die uitspattige menslike optrede van die gode van Homerus word seker die beste beskrywe in die gode-bakleiery in die Ilias 21. Mueller (1984:35) merk tereg hiervan op: "The outrageousness of the gods reaches its high (or low) point in the theomachy, the battle of the gods." Mueller vervolg deur te sê dat hierdie geen gewyde katastrofe is nie, maar eerder "in the nature of a tavern brawl".

Nogtans, alhoewel tipies menslik in hul optrede, is daar by die Homeriese gode 'n andersheid en 'n afstand tussen die wêrelde van die gode en die mense. Mueller (1984:135) sien in die god Apollo (Il. 1.43-49) 'n verpersoonliking van hierdie goddelike afstand as hy opmerk: "Apollo's bow is the perfect emblem of divine distance, destroying man from a position of remote power." Alhoewel die gode van die Ilias inmeng in die sake van mense, is konflikte tussen mense en gode, volgens Mueller (1984:128), seldsaam. In die enkele gevalle waar konflik wel plaasvind, soos in llias 5.311 waar Aphrodite haar seun Hektor probeer red teen Diomedes en gewond word deur laasgenoemde se spies, word die andersheid tussen god en mens weer eens beklemtoon deur daarop te wys dat dit nie gewone bloed nie, maar goddelike bloed is wat op die grond val.

Otto (1954:235) wys ook op die andersheid van die bestaan van die Homeriese gode teenoor die bestaan van die mens deur op te merk: "Even where they are most anthropomorphic, the primacy and eternity of their beings are superhuman." Ter versterking van sy argument haal Otto (1954:viii) ook die bekende stelling van Goethe aan waar hy opmerk dat die Grieke nie hul gode wou afbring aarde toe nie, maar eerder die mens wou verhef na die vlak van die gode: "The purpose and goal of the Greeks is to deify man, not to humanize deity. This is not anthropomorphism but theomorphism." Erasmus (1970:37) som die verhouding tussen die gode en die mense by Homerus myns insiens die beste op as hy sê dat daar nie van twee wêrelde nie, maar eerder van twee dimensies van dieselfde wêreld waarin almal onderworpe is aan die noodlot, gepraat moet word.

Die antropomorfisme van die gode by Vergilius word onder andere deur Servius (10.117) uitgewys in sy kommentaar op Aeneis 10 as hy van die toneel waar die 
gode Jupiter van die senaatshuis vergesel, opmerk dat hy (Vergilius) op digterlike wyse die gebruike van mense op gode toepas (poetice mores hominum ad deos refert: ut magistratum dedecunt). Die andersheid van die gode by Vergilius teenoor die Homeriese gode bestaan enersyds daarin dat, anders as by Homerus, die gode by Vergilius deur 'n Romeinse bril met 'n Romeinse oogmerk gesien word. Feeney (1991:217) stel dit só: "The power of the characteristic Roman way of looking at the gods comes through very strongly: they are part of the constitution, and evolve with it." Verder is die Vergiliese gode meer afsydig en verhewe as die Homeriese gode. Feeney (1991:183) merk in dié verband op: "There is indecorous divine action enough in the Aeneid, after all, and such a response may obscure the fact that Vergil's norms also result in a shutting out of the intimacy and cooperation between men and gods which is a corollary of Homer's technique." As voorbeeld van hierdie gemis aan intieme samewerking tussen gode en mense noem Feeney Boek 9 van die Aeneïs waar Juno Turnus bystaan alhoewel hy deurgaans onbewus van haar teenwoordigheid bly. By Vergilius word die prepon-tradisie betreffende styl en stof, waarvan die anonieme skrywer van die Libellus de Sublimitate (9.8 e.v.) opmerk dat bloot die voorkoms van religieuse stof sedert die laat-Hellenistiese tydvak geassosieer is met 'n verhewe stylvlak (genus grande), deurentyd gehandhaaf.

In sy Metamorphoses bring Ovidius egter die gode van Olympus nie alleen af na die strate van sy eietydse Rome nie, maar verkry sy humor grootliks deur die goddelike eienskappe van die inwoners van Olympus af te speel teen hul tipies menslike gebreke. Solodov (1988:91) merk in verband met Met. 15.773-774 (bellaque cum Turno gerere, aut, si vera fatemur, / cum Iunone magis, "die oorloë gevoer met Turnus, of as ons eerlik erken, eerder met Juno") op dat die frase ingelei deur aut, wat as 'n soort nagedagte bygevoeg word, die verhouding tussen god en mens tot die kwasi-familiêre kleur. In die Aeneïs, vervolg Solodov, was Juno die godheid wat die opposisie teen Aeneas en die Trojane gelei het. Nóg sy nóg die ander gode van Olympus het egter as 'n reël verskyn en direk ingemeng in die sake van die mensdom. Solodov (1988:91) kom in dié verband tot die volgende gevolgtrekking:

...gods and men dealt with one another, but were kept apart on separate planes. Hierarchy reigns in the Aeneid. Here, however, Ovid's Venus, in saying "against Turnus, or rather against Juno", places Juno on the same level as Turnus. There is no longer a clear distinction between the divine and the human. The gods have come to rest on earth.

Nog 'n voorbeeld waar die goddelike in die Metamorphoses afgebring word aarde toe, is in 13.91 waar Jupiter, volgens Solodov (1987:91), by wyse van zeugma gelykgestel word aan vuur en swaard:

ecce ferunt Troes ferrumque ignesque Iovemque in Danaas classes.

Kyk, die Trojane bring swaarde, vuur en Jupiter in teen die Griekse vloot. 
Die ongerymdheid tussen goddelike vermoëns en menslike swakhede by die gode manifesteer reeds in Met. 1.433 waar die leser die god Apollo aantref in die rol van 'n gefrusteerde Don Juan in sy gedoemde verliefdheid op Daphne, volgeling van Artemis, godin van jag en kuisheid. Ironies genoeg kan Apollo, god van profesie, nie insien dat sy liefde vir Daphne tot vergeefsheid gedoem is nie. Die Olimpiese perspektief van die god Apollo word hier dus vereng tot blote menslike stiksienigheid:
Phoebus amat visaeque cupit conubia Daphnes, quod cupit sperat, suaque illum oracula fallunt, utque leves stipulae demptis adolentur aristis, ut facibus saepes ardent, quas forte viator vel nimis admovit vel iam sub luce reliquit, sic deus in flammis abiit, sic pectore toto uritur et sterilem sperando nutrit amorem.

Phoebus raak verlief en nadat hy Daphne gesien het, begeer hy 'n huwelik met haar en hy vestig sy hoop op wat hy begeer, sy eie orakels bedrieg hom. En soos ligte strooi verbrand word nadat die koringare afgeoes is, soos heinings aan die brand slaan weens fakkels wat 'n reisiger per ongeluk te naby gebring het of teen dagbreek agter gelaat het, so het die god in sy hele wese ontbrand.

Ook in die verhaal van Apollo en Hiasinthus in Met. 10.189 kom die feitlik menslike onmag van die god duidelik na vore as hy as god van genesing magteloos staan (nil prosunt artes) om sy geliefde van die dood te red. Nog 'n voorbeeld waar die menslike eienskappe veroorsaak dat die status van 'n god afdaal na menslike vlak word gevind in Met. 2.731-736 waar Mercurius, goddelike boodskapper, treffend as verliefde tiener voorgestel word. Mercurius, in sy vlug, sien die skone Herse op aarde:

Jove's son, breath-taken by her loveliness,

Was kindled as he hovered, like a lead

Slung from a Spanish sling, that as it flies

Glows with its speed and finds below the clouds

Heat not its own. Swerving, he left the sky

And flew to earth, and there took no disguise -

Such trust in his good looks! Yet though his trust

Was sound, he spared no pains; he smoothed his hair,

Arranged his robe to hang aright, to show

The whole long golden hem, saw that his wand,

... Shone with a polish, and his ankle-wings

Were lustrous and his sandals brushed and clean.

(Vertaling deur Melville)

Anders as by Vergilius waar, soos reeds hierbo opgemerk, bloot die melding van die gode dikwels aanleiding gee tot 'n verhewe stylvlak (genus grande), kom patos, eie 
aan 'n verhewe stylvlak, in die Metamorphoses, volgens Otis (1966:166 e.v.) veral voor waar liefde ter sprake is eerder as waar dit net om die gode gaan. Otis sonder die liefdespatos in Met. 6-11 uit in dié verband. In die Metamorphoses gee liefde eerder as gode dus aanleiding tot patos. Die liefde en menslike lyding in die Metamorfoses laat die stylvlak dus styg, maar selfs hier, soos in Met. 4.55, kan die volgehoue humoristiese inslag (perpetua festivitas) van die outeur nie heeltemal gedemp word nie en word die patos doelbewus deur 'n hiperboliese similee op lagwekkende wyse deurbreek:

Then drew his sword and plunged it in his side. And quick from the warm wound withdrew the blade. And as he lay outstretched his blood leaped high, as when a pipe bursts where the lead is flawed and water through the narrow hissing hole shoots forth long leaping jets that cut the air.

(Vertaling deur Melville)

Die moontlikheid van 'n gelykstelling tussen mens en god, wat reeds in die antropomorfiese hantering van die gode by Homerus en Vergilius 'n moontlikheid was, maar nooit ten volle gerealiseer het nie, word feitlik tot volle konsekwensie gevoer deur Ovidius. Volgens Feeney (1991:198) is dit slegs die licentia van die gode by Ovidius wat hul onderskei van die mense.

\subsection{Die rol van die outeur in die Metamorphoses ${ }^{2}$}

Volgens Solodov (1988:72) is die prepon-norm vir die rol van 'n outeur van 'n verhalende gedig reeds deur Homerus neergelê. Aristoteles (Poet. 60a.5-7) ${ }^{3}$ sonder Homerus naamlik uit vir sy relatiewe afwesigheid van die verhaalwêreld van die gedig self: "Homerus verdien lof op grond van vele dinge, maar veral omdat hy alleen onder die digters besef wat die digter behoort te doen: die digter self moet so min as moontlik praat." Volgens Solodov (1988:72) het hierdie prepon-tradisie tot in Romeinse tye bly voortleef. Hier het die situasie eers by Vergilius en later by Ovidius verander.

Die teenwoordigheid van die outeur, vervolg Solodov, word weliswaar dwarsdeur die Aeneis aangevoel. By Vergilius word die teenwoordigheid van die outeur egter aangevoel as empatiese meelewing met sy karakters, wat onafhanklik van hul skepper optree. Die outeur van die Metamorphoses, aan die ander kant, staan nie alleen meer onbetrokke en objektief teenoor sy karakters nie, maar oorheers die hele toneel en gaan selfs so ver as om sy eie verhaal se geloofwaardigheid te bevraagteken. So laat hy die karakter-verteller Nestor in Met. 12.545 verbasend uitroep dat Hercules se dade darem te ver gaan om geloofwaardig

2 Met outeur word hier in narratologiese terme beide die implisiete outeur, wat as alomteenwoordige bewussyn die verhaal dirigeer (kyk Bal 1980:124), sowel as die ouktoriële verteller as primêre spreekbuis van die outeur, bedoel.

3 Kyk ook Erasmus 1970:24 in dié verband. 
te wees (ille quidem, maiora fide, di gessit!). Die outeur se skeptiese ingesteldheid teenoor die verhaal wat hy vertel, kom ook mooi na vore in Met. 10.28-29 waar Orpheus voor Pluto en Proserpina pleit vir Euridice en dan sê dat as 'n mens die ou verhaal van die verkragting kan glo dan het Liefde hulle ook maar byeen gebring (famaque si veteris non est mentita rapinive, vos quoque iunxit Amor).

Nie alleen vind die totale fokalisasie feitlik deurgaans plaas vanuit die gesigspunt van die outeur nie, maar hy val sy karakters selfs in die rede en vul inligting aan wat ontbreek. Solodov (1988:73) merk in dié verband op: "The hero Ovid is active in several fields. As he continually reminds us, he has created the world of the poem, he has brought it into existence and shaped it. $\mathrm{He}$ is also one of the chief elements holding it together." Soms breek die outeur, volgens Solodov (1988:65) selfs met epiese volledigheid en objektiwiteit deur self te kies wat hom pas. In Met. 13.493 sê die outeur byvoorbeeld dat Hecuba weliswaar meer dinge gesê het, maar dat die volgende uit haar verskeurde hart voorgekom het (Hecuba, plura quidem, sed haec laniato pectora dixit).

Ons kan die rol van die outeur in die Metamorphoses dus in sekere sin vergelyk met dié van 'n regisseur wat die kalklig voortdurend op homself wil laat val en sy karakters gevolglik laat inboet aan geloofwaardigheid. Alhoewel hy dit nie altyd in narratologiese terme doen nie, vestig Solodov (1988:3 e.v.) die aandag van die leser op verskeie aspekte en tegnieke in die Metamorphoses wat verseker dat die kalklig deurentyd op die briljantheid van die outeur val. Die volgende word hier uitgelig:

\section{- Genialiteit van die outeur}

Die geniale wyse waarop die meer as 200 mites tot 'n perpetuum carmen (aaneenlopende gedig) verweef word, spreek van vindingrykheid aan die kant van die outeur wat die leser se aandag verskuif van die verhaal na die outeur se genialiteit. Opvallend hier is veral die transitiones per absentem-oorgange (oorgange bewerkstellig deur die afwesigheid van ' $n$ bepaalde karakter) van een mitiese verhaal na die volgende. 'n Goeie voorbeeld hiervan word aangetref in Met. 11.90-92, waar Bacchus die Thrakiese vroue gestraf het vir die moord op Orpheus en met sy geselskap vertrek na Lydia. Almal is teenwoordig behalwe Silenus. Die outeur gebruik dan sy verduideliking van waar Silenus was om sodoende aansluiting te vind by die verhaal van koning Midas wat deur sy aanraking alles in goud laat verander het.

Nog 'n voorbeeld van die briljantheid van die outeur van die Metamorphoses word gevind in die skerpsinnige epigrammatiese segswyses wat óf gelê word in die mond van 'n karakter óf verwoord word deur die ouktoriële verteller self. 'n Voorbeeld hiervan word aangetref in Met. 1.628-629 waar Argus met sy honderd oë Io in opdrag van Juno bewaak, en wat soos volg deur die ouktoriële verteller beskrywe word: 
constiterat quocumque modo, spectabat ad Io;

ante oculos Io, quamvis aversus, habebat.

Hoe hy ookal gestaan het, het hy Io onder oë gehad, Io voor hom, Io agter hom.

Treffend is ook die skerpsinnige opmerking gelê in die mond van Narcissus in Met. 3.473 waar Narcissus na sy eie spieëlbeeld in die water kyk:

nunc duo concordes anima moriemur in una.

Nou sal ons twee harte in een siel sterf.

\section{- Oorheersing deur die ouktoriële verteller}

By Homerus val een spreker volgens Erasmus (1970:29) nie sommer 'n ander spreker in die rede nie. Daarvoor, sê Erasmus, was die Grieke te waardig. In die Metamorphoses, soos in 1.700-712, neem die ouktoriële verteller selfs by tye die vertelling by ' $n$ karakter oor. Hier is Mercurius besig om 'n verhaal aan Argus te vertel ten einde hom, in opdrag van Jupiter, aan die slaap te sus. Argus raak aan die slaap en Mercurius staak sy vertelling. Die ouktoriële outeur neem dan oor en voltooi die verhaal:

talia verba refert ... restabat verba referre, et precibus spretis fugisse per avia nympham donec harenosi placidum Ladonis ad amnem venerit...

Sulke woorde spreek hy ... die woorde dat die nimf sy bedes geminag het en deur onbegaanbare plekke gevlug het totdat sy die rustige stroom van sandryke Ladon bereik het, moes nog vertel word.

\section{$3 \quad$ Slotsom}

Uit die voorafgaande is dit dus duidelik dat die outeur van die Metamorphoses in vele opsigte breek met dit wat tot op sy dag tradisioneel as prepon beskou is. Opvallend is veral die egosentriese toe-eiening van die kalklig vir die outeur self. Ná die lees van die Ilias en die Odusseia of van Vergilius se Aeneïs, bly die herinneringe aan sekere helde en gebeurtenisse in die leser se gedagtes voortlewe. Ná die lees van die Metamorphoses is dit die briljantheid van die outeur of ouktoriële verteller wat in herinnering bly. Solodov (1988:37) merk tereg in dié verband op: "One thing does stand out, dominating and informing the whole: the narrator himself...." 


\section{BIBLIOGRAFIE}

Bal, M 1980. De theorie van vertellen en verhalen. Muidenberg: Coutinho.

Barnes, Hazel E 1974. The meddling gods. Lincoln: University of Nebraska Press.

Brink, C O 1971. Horace on poetry: The Ars Poetica. Cambridge: Cambridge University Press.

Cairns, F 1988. Virgil's Augustan epic. Cambridge: Cambridge University Press.

Drijepondt, H L F 1979. Die antike Theorie der varietas. Hildesheim: Olms.

Erasmus, A H 1970. Die epos in klassieke Grieks. In Cronjé, G (red), Die epos. Pretoria: Van Schaik.

Erbse, H 1.986. Untersuchungen zur Funktion der Götter in homerischen Epos. Berlin: de Gruyter.

Feeney, D C 1991. The gods in epic. Oxford: Clarendon Press.

Frécaut, Jean-Marc 1972. L'esprit et l'humour chez Ovide. Presses universitaires de Grenoble.

Galinsky, G K 1975. Ovid's Metamorphoses and the traditions of Augustan poetry. Cambridge: Cambridge Philological Society.

Gransden, K W 1990. Virgil: The Aeneid. Cambridge: Cambridge University Press.

Heinze, R 1993. Virgil's epic technique. Bristol: Bristol Classical Press.

Hendricks, Rhoda A 1972. Classical gods and heroes. New York: Frederick Ungar Publishing.

Kerenyi, C 1961. The gods of the Greeks. London: Thames and Hudson.

Melville, A D 1986. Metamorphoses. Oxford: Oxford University Press.

Mueller, M 1984. The Iliad. London: George Allen \& Unwin.

Ogilvie, R M 1981. The Romans and their Gods. In Finley, M I (ed), Ancient culture and society. London: Chatto \& Windus.

Otis, B 1966. Ovid as an epic poet. Cambridge: Cambridge University Press.

Otto, W F 1954. The Homeric gods. London: Thames and Hudson.

Pohlenz, M 1933. To Prepon: Ein Beitrag zur Geschichte des griechischen Geistes. Altertumswissenschaft 16:53-92.

Solmsen, F 1941. The Aristotelian tradition in ancient rhetoric. American journal of philology 2:35-50, 169-190.

Solodov, J B 1988. The world of Ovid's Metamorphoses. Chapel Hill \& London: University of North Carolina Press. 